\title{
Identification of multiple widespread tephras from the volcanic glass shard chemistry of muddy sediments of the Nohbi Formation, central Japan
}

\author{
Seiji Maruyama*1,2, a Takeshi Makinouchi*3, Takafumi Hirata*4, and Tohru Danhara*1
}

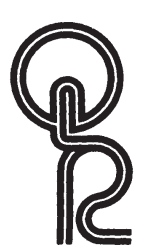

\begin{abstract}
Volcanic glass shards in muddy sediments of the late Pleistocene Nohbi Formation of central Japan are considered to be derived from multiple tephras, although the shards have petrographic properties similar to those of the Aira-Tn tephra. Hierarchical cluster analysis of concentration data for 58 elements obtained by laser ablation-inductively coupled plasma-mass spectrometry was used to distinguish glass populations in muddy sediment samples from the Nohbi Formation. Cluster analysis of volcanic glass shards from a sample in the lowermost horizon (Nohbi 38-54) of the formation identified the Aira-Tn (44\%), Ontake-Pm1 (33\%), and Ebisutouge-Fukuda (23\%) tephras. Glass shards from another sample in the middle horizon (Nohbi 60-2) of the formation were identified as being the Aira-Tn (35\%) and Ebisutouge-Fukuda (65\%) tephras. The combination of multi-element data and cluster analysis demonstrates that the muddy sediment layers contain several tens of percent of Aira-Tn glass shards, as suggested by previous studies. The Aira-Tn tephra is the youngest one within the tephras identified from the Nohbi muddy sediments. As suggested by the previous studies, this evidence indicates that the Nohbi Formation was deposited during and/or after the AT ash fall stage and before the deposition of the Nan'yo Formation.
\end{abstract}

Keywords : tephra, volcanic glass shards, muddy sediment, Nohbi Formation, cluster analysis, LA-ICP-MS

\section{Introduction}

The Nohbi Plain is a typical coastal alluvial plain in the central region of Honshu Island, Japan (Fig. 1). Subsurface geology of the Nohbi Plain consists of the Nan'yo, Nohbi, First Gravel, Atsuta, Second Gravel, Ama, Third Gravel, and Yatomi Formations, in descending order. Depositional process in the Nohbi Plain is controlled by a westward tilting which brings a sedimentary basin (Kuwahara, 1968), and glacial eustasy also influ- ences the sedimentary facies. The formations of the Nohbi Plain are mainly composed of alternating sand-gravel sediments during regressive intervals and marine muds during transgressive intervals (Sugai et al., 2016). These formations become thicker and deeper toward the west owing to the tilting. The late Pliocene-early Pleistocene Tokai Group (non-marine) underlies these formations (e.g., Kuwahara, 1985 ; Kuwahara and Makinouchi, 1988).

Among these formations, the Holocene Nan'yo,

Received November 1, 2018. Accepted May 25, 2019.

*1 Kyoto Fission-Track Co., Ltd. 44-4 Oomiyaminamitajiri-cho, Kita-ku, Kyoto, 603-8832, Japan.

*2 Research Center for Knowledge Science in Cultural Heritage, Doshisha University. 1-3 Tatara Miyakodani, Kyotanabe, Kyoto, 610-0394, Japan.

*3 Department of Environmental Science and Technology, Faculty of Science and Technology, Meijo University (Emeritus). 1-501 Shiogamaguchi, Tempaku-ku, Nagoya, 468-8502, Japan.

*4 Department of Geology and Mineralogy, Faculty of Science, Kyoto University. Kitashirakawaoiwake-cho, Sakyo-ku, Kyoto, 606-8502, Japan. (Current address : Geochemical Research Center, Graduate School of Science, The University of Tokyo. 7-3-1 Hongo, Bunkyo-ku, Tokyo, 113-0033, Japan.)

*a Corresponding author : ojigibito@icloud.com 


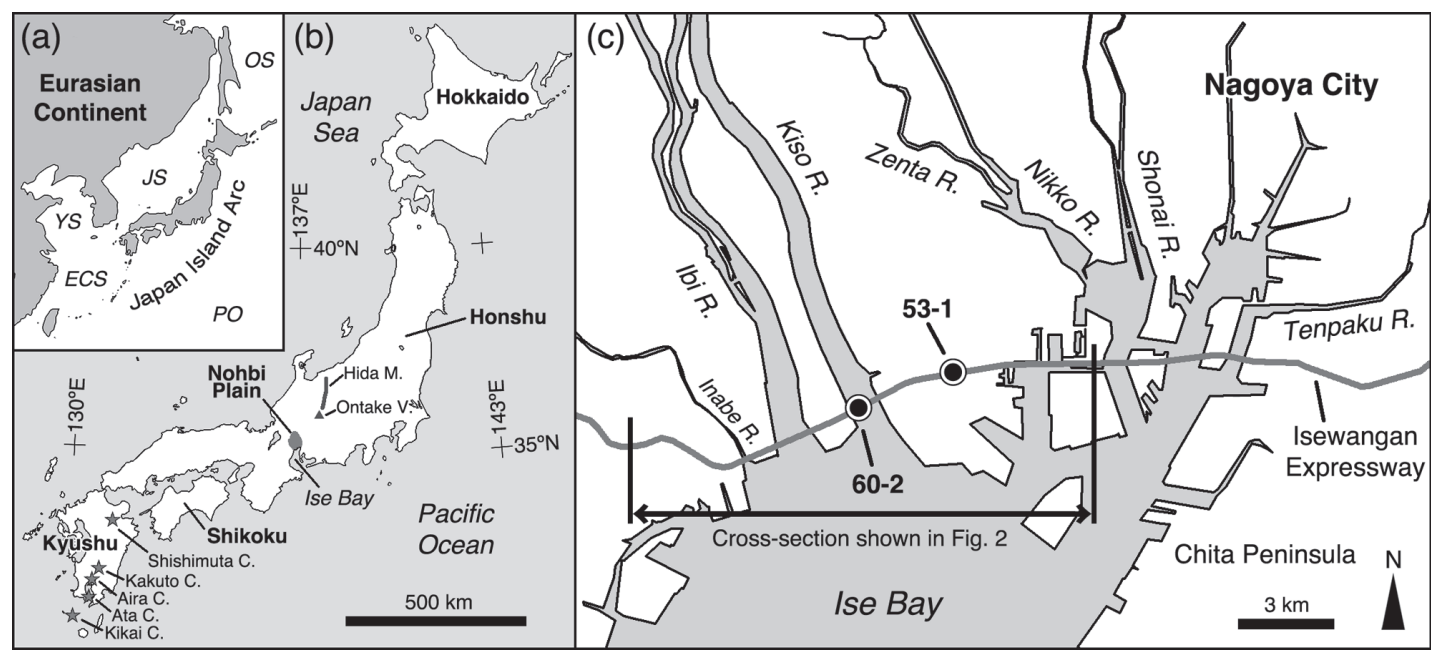

Fig. 1 Locations of the (a) Japan island arc, (b) Nohbi Plain on Honshu Island, Japan, and (c) core drilling sites from which the studied muddy sediment samples of the Nohbi Formation were obtained

The cross-section shown in Fig. 2 is along the Isewangan (the coast of Ise Bay) Expressway. The Nohbi 38-54 and 60-2 muddy sediment samples were obtained from core samples 53-1 and 60-2, respectively. The Aira, Ata, and Kikai calderas, which are regarded as the source volcanoes of AT, Ata-Th, and K-Tz, respectively, were first proposed by Matumoto (1943). The buried Shishimuta caldera, which is regarded as the source volcano of Ss-Pnk (Machida and Arai, 2011), was identified by Kamata (1989). The Kakuto caldera has been considered as the source volcano of Kkt (e.g., Aramaki and Ui, 1976). The presumed source volcanoes of On-Pml, and Ebs-Fkd and Tky-Ng1 (i.e., the Ontake Volcano and the Hida Mountaines, respectively) are described in the main text. JS=Japan Sea ; YS = Yellow Sea ; ECS = East China Sea ; OS= Okhotsk Sea ; PO=Pacific Ocean ; Hida M.= Hida Mountains ; Ontake V.=Ontake Volcano ; C.= caldera.
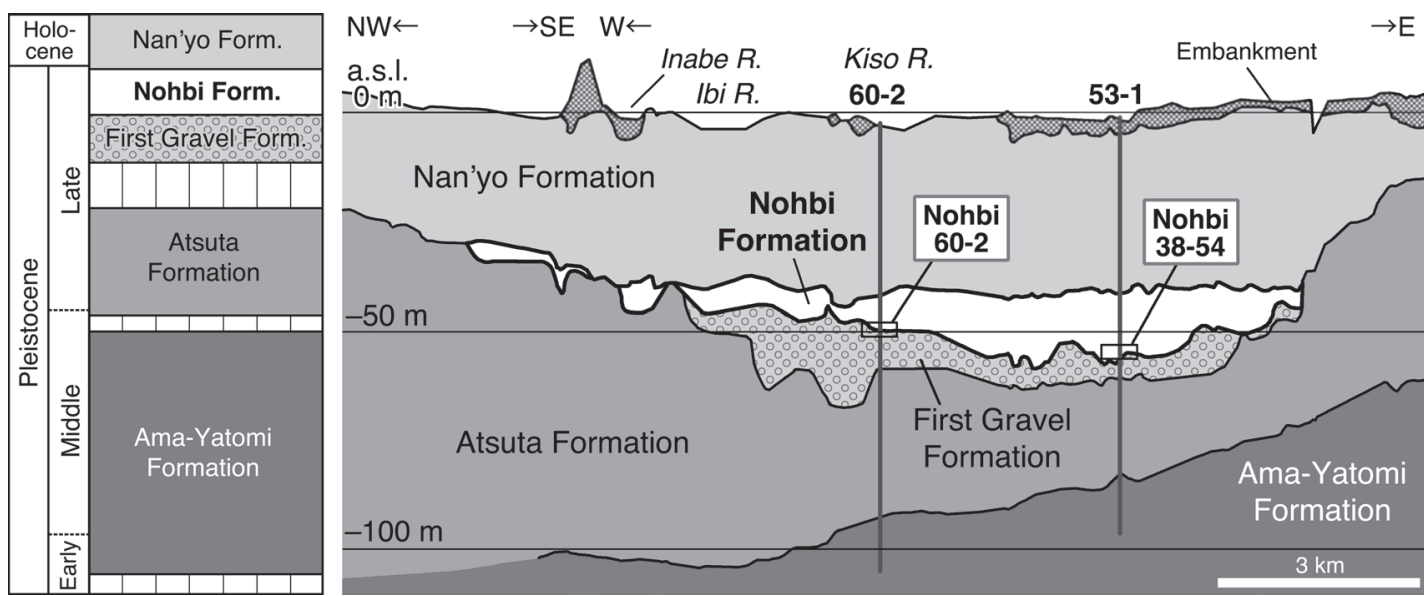

Fig. 2 An E-W-oriented cross-section showing the subsurface stratigraphy of the coastal area based on fig. 2 of Makinouchi et al. (2001) and Fig. 1 of Makinouchi et al. (2013)

The cross-section is along the Isewangan Expressway (fig. 1). The studied muddy sediment samples were obtained from the depths indicated by the boxes in the figure. a.s.l. = above sea level. 
late Pleistocene Nohbi, and First Gravel Formations constitute at or near the surface sediments of the Nohbi Plain (Fig. 2), and are regarded as being transgressive- and alluvial-facies formations (e.g., Matsuzawa and Kato, 1954 ; Iseki, 1962 ; Nobi Plain Quaternary Research Group, 1977). The Nohbi Formation (Furukawa, 1972) comprises mainly sand and mud layers, and the sand layers are well compacted ( $N \geq 30$; Makinouchi et al., 2001). Volcanic glass shards are scattered throughout the sediment layers (Fig. 3). A detailed overview of the subsurface geology of the Nohbi Plain was given by Makinouchi et al. (2001, 2006, 2013). Hori et al. (2019) have reviewed in detail the recent research trends of the Nan'yo, Nohbi, and First Gravel Formations.

On the basis of the shapes and refractive indices of volcanic glass shards in the Nohbi Formation sediments, Makinouchi et al. (2001) argued that those in the middle horizon of the formation could be correlated with the Aira-Tn (AT) widespread marker tephra, which was erupted from

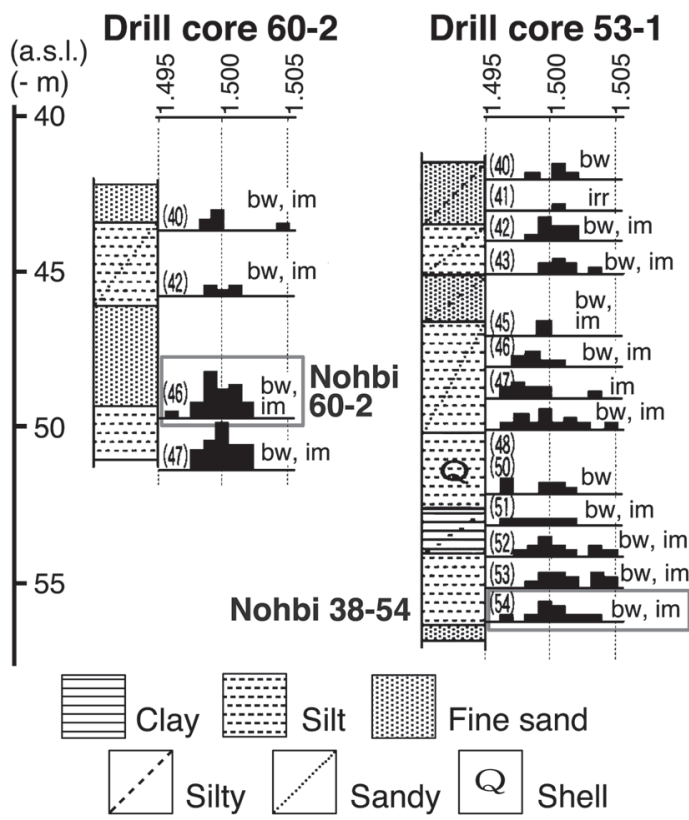

Fig. 3 Columnar sections of drill cores 60-2 and 53-1 with refractive indices and shapes of volcanic glass shards based on fig. 6 of Makinouchi et al. (2001)

Classification of the shape of volcanic glass shards is based on Yoshikawa (1976) : bw = bubble wall type, im = intermediate type, and irr=irregularly shaped type.
Aira caldera in southern Kyushu Island (Fig. 1-b ; e.g., Machida and Arai, 2011). The eruption age of the AT tephra is currently estimated at $30,078 \pm$ 96 cal yr BP, based on ${ }^{14} \mathrm{C}$ dating of drill core samples from Lake Suigetsu (Albert et al., 2018). Makinouchi et al. $(2001,2006)$ estimated the age of the Nohbi Formation to be 20-30 ka, based on the presence of AT volcanic glass shards. However, this estimate is unreliable because of lack of chemical data of the volcanic glass shards.

In this paper, we present major and trace element data for volcanic glass shards in the Nohbi Formation muddy sediments, obtained by laser ablation-inductively coupled plasma-mass spectrometry (LA-ICP-MS), along with a statistical analysis of these data. Multivariate statistical treatments such as Q-mode factor analysis (QFA) and constrained least-squares (CLS) multiple linear regression techniques have been used for the partitioning of geochemical datasets of bulk sediments and ash layers (e.g., Pisias et al., 2013 ; Scudder et al., 2018). In this study, hierarchical cluster analysis was used to partition the geochemical datasets from two muddy sediment samples from the Nohbi Formation. The cluster analysis successfully identified different tephra units in these samples, including the AT tephra.

\section{Samples and analytical methods}

\section{Samples}

The abbreviations for the tephras referred to in this study are based on Machida and Arai (2011). The Nohbi Formation muddy sediment samples (Nohbi 38-54 and 60-2) in the present study correspond to samples 53-1 (54) and 60-2 (46), respectively, described by Makinouchi et al. (2001). Samples 38-54 and 60-2 are from the lowermost and middle horizons of the Nohbi Formation, respectively, and have higher volcanic glass contents. These samples were obtained from drill cores for the standard penetration test used to draw a geological cross-section (Isewangan Expressway) of the coastal area of the Nohbi Plain (Figs. 1 and 2 ; Makinouchi et al., 2001). Volcanic glass comprises $\sim 1$ and $\sim 5.5 \mathrm{wt} . \%$ of the sieved samples with a grain size of \#120-250 (i.e., $0.063-0.125 \mathrm{~mm}$ ) from the $38-54$ and $60-2$ samples, respectively. Therefore, the volcanic glass shards actually comprise $<0.01 \mathrm{wt} . \%$ of these sediments. The distributions of the refrac- 
tive indices of the 38-54 and 60-2 volcanic glass samples are shown in Fig. 3. The refractive indices of these glasses in both samples are 1.498-1.501, and the shard shapes are the bubble wall (Henpei of Yoshikawa, 1976) or intermediate (Chukan of Yoshikawa, 1976) types, with the latter being transitional between the bubble wall and pumiceous (Takoushitsu of Yoshikawa, 1976) types (Fig. 3). The volcanic glass shards have been hydrated almost completely.

The elemental data for the Nohbi Formation samples were compared with some representative marker tephras whose volcanic glass shards show refractive indices around 1.500. According to fig. 7 of Makinouchi et al. (2001), those for the AT, Kikai-Tozurahara (K-Tz), Ata-Toihama (AtaTh), and Shishimuta-Pink (Ss-Pnk) tephras from the calderas of Kyushu (Fig. 1-b) were compared. The refractive indices of the volcanic glass shards of these tephras distribute around 1.500 (e.g., Machida and Arai, 2011). However, the volcanic glass shards of the Amagi-Kawagodaira (Kg) (1.498-1.506 ; Shimada, 2000), Kakuto (Kkt) (1.500-1.502 ; Machida and Arai, 2011) and Seiganji-Toga (Se-Tg) (1.500-1.505 ; Machida and Arai, 2011) tephras shown in Fig. 7 of Makinouchi et al. (2001) were not analyzed in this study. The sampling locations of the samples of the AT, Ata-Th, K-Tz, and Ss-Pnk (Osaka Group Pink ; OGPK) tephras were described by Maruyama $e t$ al. (2018).

In addition to these tephra samples, the elemental data for the samples of the EbisutougeFukuda (Ebs-Fkd), Ontake-Pm1 (On-Pm1), and Takayama-Ng1 (Tky-Ng1) tephras were compared with those for the Nohbi Formation samples. These well-characterized representative marker tephras are important because the presumed source volcanoes are near the Nohbi Plain, although Makinouch et al. (2001) did not mention Ebs-Fkd. The refractive index of the volcanic glass shards of Ebs-Fkd is 1.500-1.503 (Machida and Arai, 2011), which is similar to those of the Nohbi Formation samples (Fig. 3). The source volcano of the Ebs-Fkd tephra is presumed to be in the Hida Mountains (Fig. 1-b ; Nagahashi et al., 2000), which is $\sim 160 \mathrm{~km} \mathrm{NNE}$ of the sampling sites of the studied Nohbi Formation samples. Machida and Arai (2011) proposed that the eruption age of Ebs-Fkd was $1.7 \mathrm{Ma}$. The Ebs-
Fkd tephra was distributed widely over Honshu Island, and its estimated thickness on the Nohbi Plain is $>50 \mathrm{~cm}$ (Machida and Arai, 2011). The eruption age of the Tky-Ng1 tephra, which is presumed to be sourced from the Hida Mountains (Fig. 1-b ; Kajita and Ishihara, 1977 ; Kondo, 1985 ; Mizuno and Kikkawa, 1991), is estimated to be $\sim 0.3 \mathrm{Ma}$, and the tephra is distributed from Shikoku to the Kanto district on Honshu Island (Mizuno and Kikkawa, 1991). Ontake volcano to the south of the Hida Mountains (Fig. 1-b) is $~ 110$ $\mathrm{km}$ NE of the sampling sites of the studied Nohbi Formation samples. This is regarded to be the source volcano of the On-Pm1 tephra (e.g., Kobayashi et al., 1967 ; Takemoto et al., 1987). Machida and Arai (2011) proposed an age of 100-95 ka for the On-Pm1 tephra. The On-Pm1 tephra is distributed mainly towards the Kanto and Tohoku districts, which is in the opposite direction to the Nohbi Plain. However, this tephra was supplied to the Nohbi Plain through the Kiso River, and has been found in the Atsuta Formation below the Nohbi Formation (Fig. 2) (Kobayashi et al., 1967). The Kiso River flows down southeast side of Ontake volcano.

The Ontake-Yabuhara (On-Yb) and OntakeTatsuno (On-Tt) tephras (Takemoto et al., 1987) from Ontake volcano were also shown in Fig. 7 of Makinouchi et al. (2001) as the tephras whose volcanic glass shards show the refractive indices around 1.500. However, considering that the refractive index strongly reflects the major element composition of the volcanic glass shard (Nagahashi et al., 2004), the chemical properties of the volcanic glass shards of the $\mathrm{On}-\mathrm{Yb}$ and On-Tt tephras may be almost identical to that of the On-Pm1 tephra. Therefore, the On-Pm1 tephra is treated as a representative tephra sample from Ontake Volcano in this study.

The sampling locations of the samples of the Ebs-Fkd tephra was described by Maruyama et al. (2018). The Tky-Ng1 tephra sample was obtained from Kokawadera, Kinokawa City, Wakayama Prefecture. The On-Pm1 tephra sample was obtained from a cliff around InaToubu Junior High School, Hikage, Ina City, Nagano Prefecture. The refractive indices of the volcanic glass shards of the Nohbi Formation samples (Fig. 3) and the representative marker tephras (i.e., AT, K-Tz, On-Pml, Ata-Th, 
Tky-Ng1, Ss-Pnk, and Ebs-Fkd) were determined using a refractive index measurement system (RIMS ; Kyoto Fission-Track Co., Ltd. ; Danhara et al., 1992). The petrographic properties of the samples of these representative marker tephras were completely consistent with those briefly described by Machida and Arai (2011).

\section{LA-ICP-MS analyses}

Determination of 58 major and trace elements in the Nohbi Formation volcanic glass shards was undertaken with a Thermo Fisher Scientific iCAP Qc quadrupole ICP-MS instrument coupled to an ESI NWR-193 excimer laser ablation (NWRexLA) system at Kyoto University, Japan. The wavelength and duration of the laser pulse were $193 \mathrm{~nm}$ and $5 \mathrm{~nm}$, respectively. The laser repetition rate and fluence were set to $5 \mathrm{~Hz}$ and $3.0^{-}$ $3.2 \mathrm{~J} / \mathrm{cm}^{2}$, respectively. The beam diameter was $15 \mu \mathrm{m}$ and the ablation duration was $20 \mathrm{~s}$ for each analysis. Only one analysis was performed on each glass shard.

Volcanic glass shards in the tephra samples whose analytical data were compared with those for the Nohbi Formation samples were analyzed using an iCAP Qc ICP-MS coupled to an ESI NWR-Femto femtosecond LA (NWR-fsLA) system at Kyoto University, Japan. The wavelength and duration of the laser pulse were $260 \mathrm{~nm}$ and $600 \mathrm{fs}$, respectively. The laser repetition rate, fluence, and beam diameter, and duration of analysis, were the same as those of the NWRexLA analyses. The detailed analytical protocols for the NWR-fsLA and -exLA analyses are described by Maruyama et al. (2016a, b, 2017).

Volcanic glass shards from the AT tephra were analyzed by both NWR-fsLA and -exLA techniques. In addition, a single AT volcanic glass shard was analyzed using an iCAP Qc ICP-MS coupled to a Cyber Laser IFRIT femtosecond LA (CL-fsLA) system at the University of Tokyo, Japan, to compare results obtained under different LA conditions. The wavelength and duration of the laser pulse were $260 \mathrm{~nm}$ and $190 \mathrm{fs}$, respectively. The laser repetition rate and fluence were set to $10 \mathrm{~Hz}$ and $\sim 9.8 \mathrm{~J} / \mathrm{cm}^{2}$, respectively. Under these conditions, the pit diameter (i.e., beam diameter) was $15-20 \mu \mathrm{m}$. The ablation duration was set to $20 \mathrm{~s}$ for each analysis. The other CL-fsLA analytical protocols were essentially the same as those summarized by Maruyama et al. (2016a, b, 2017).

Two synthetic silica-soda-lime glasses distributed by the National Institute of Standards and Technology (NIST ; NIST SRM 610 and 612) were repeatedly analyzed as reference materials. The reference values of these standard glasses reported by Jochum et al. (2011) were used for calibration in this study. The analyzed isotope data were obtained by integrating measurement cycles from the beginning to the end of the signal peak. The number of integration cycles was 20 for the NWR-exLA and -fsLA analyses, and 22 for the CL-fsLA analyses. The integrated background signal just before each analysis was subtracted from the analysis signal of each isotope. The number of background integration cycles was the same as that for the signal peaks. The background-corrected data were converted to elemental concentrations using the NIST data, and then internally normalized to measured silicon concentrations. Additional details of the data processing are described by Maruyama et al. $(2016 \mathrm{a}, \mathrm{b})$. The data obtained in this study are summarized in Appendix S1. The data for the K-Tz, Ata-Th, Ss-Pnk (OGPK) tephras, and the AT tephra obtained by NWR-fsLA were published by Maruyama et al. (2017) as supplementary material. The optical images of the volcanic glass shards after LA were taken with a Leica DVM5000 HD digital microscope.

3. Hierarchical cluster analysis of elemental data

Hierarchical cluster analysis of the elemental data was used to statistically identify glass populations. Cluster analysis has been previously used for classification of geological materials (e.g., Parks, 1966 ; Rhodes, 1969 ; Till, 1974). In the field of tephrochronology, cluster analysis has been tested and used for the evaluation of tephra relationships (e.g., Kikkawa et al., 1989 ; Baron et al., 2008 ; Tryon et al., 2008 ; Lowe et al., 2017). The cluster analysis was performed using the $\mathrm{R}$ software package (R Core Team, 2019). The cluster analyses of the AT, Ebs-Fkd, On-Pm1, and Tky-Ng1 tephra data were carried out to estimate the range of the maximum heights of pure tephra samples, and compared the maximum heights of the branches of the dendrograms with the results of the cluster analyses for the Nohbi Formation samples. The further neighbor (or 
complete linkage) method was used for the hierarchical cluster analysis. Distances or lengths of branches in the dendrograms between the analysis spots are represented as Euclidean distances. The Euclidean distances obtained by the cluster analyses are summarized in Appendix S2.

A combination of the wt.\% values for nine major elements and $\mu \mathrm{g} / \mathrm{g}$ values for 49 trace elements were used for the cluster analysis. In preliminary tests, a dataset of element concentrations normalized relative to crustal abundances was used. However, the results of these tests were not as good as simply using measured concentration data.

In other preliminary tests, data for some elements (e.g., Be, Ni, Mo, Ag, Cd, In, and Sn), whose analytical values are relatively low and/ or slightly scattered, had a negligible effect on the cluster analysis results. However, the data for these elements were included in the final cluster analyses in order to utilize as many discriminating factors as possible.

\section{Results and discussion}

\section{Difficulties in glass identification}

The distribution of volcanic glass refractive indices in the Nohbi Formation samples (Makinouchi et al., 2001) can constrain the tephras that might be present in these samples. The glass refractive indices in the 60-2 sample have two peaks at around 1.500 (Fig. 3 ; Makinouchi et al., 2001). The lower (1.499) and higher (1.501) peaks (Fig. $3)$ correspond to those in the AT (1.498-1.501) and Ebs-Fkd (1.500-1.503) tephras (Machida and Arai, 2011), respectively. Moreover, the mode of the refractive indices and the shapes of the glass shards in the sample 38-54 (Fig. 3 ; Makinouchi et al., 2001) suggest that the AT tephra $($ mode $=1.499-1.500$; Machida and Arai, 2011) is a dominant component in this sample. The refractive indices of volcanic glass shards in the On-Pm1 tephra are identical to those of the Ebs-Fkd tephra (1.500-1.503 ; Machida and Arai, 2011), and those of the Tky-Ng1 tephra are similar to those of the AT tephra (1.498-1.500 ; Machida and Arai, 2011). Therefore, these tephras, which were erupted in and/or near the Hida Mountains, should be considered candidates for correlation with the Nohbi Formation samples.
The Ebs-Fkd, On-Pm1, and Tky-Ng1 tephras are only candidates whose source volcanoes are near the Nohbi Plain from the similarity of the refractive indices of the volcanic glass shards.

In some previous studies, major and some trace elements (e.g., Sr, Y, Ba, and La) in volcanic glass shards obtained by ICP emission analysis have been used for tephra correlation and identification (e.g., Kikkawa et al., 1989 ; Kikkawa, 1990 ; Tamura et al., 2005, 2008). These relatively abundant trace elements (normally several tens to hundreds of $\mu \mathrm{g} / \mathrm{g}$ in rhyolitic glass shards ; e.g., Maruyama et al., 2016a, 2017) can be used to robustly identify and correlate individual tephras (e.g., Nogami et al., 2018). Based on the glass refractive index data, we compared the chemical compositions of the volcanic glass shards from the Nohbi Formation samples and some representative marker tephras described above. Figure 4 shows a plot of $\mathrm{Ba} / \mathrm{La}$ versus $\mathrm{La} / \mathrm{Y}$ for the volcanic glass shards of the Nohbi Formation samples, along with data for eight tephras whose volcanic glass shards show similar refractive indices to those of AT for comparison. Although the Kkt sample has not been analyzed in this study, the analysis data obtained by Kimura et al. (2015) are available for this comparison. Figure 4 clearly shows that the K-Tz, Tky-Ng1, and Kkt tephras are absent in the Nohbi Formation samples. The data for sample 38-54 mainly overlap with those of AT, On-Pm1, and Ss-Pnk, although some data are slightly scattered (Fig. 4-a). Figure 4-a shows that the volcanic glass shards in sample 38-54 contain the AT and OnPml tephras, but the presence of Ata-Th, SsPnk, and Ebs-Fkd is equivocal. On the other hand, data for sample 60-2 almost overlap with those of AT, Ata-Th, and Ebs-Fkd (Fig. 4-b), but On-Pm1 and Ss-Pnk are not present.

There are still some ambiguities in distinguishing glass populations from these trace elements, given the slightly scattered data for sample 38-54 (Fig. 4-a). In particular, the data for analytical spots A-M and A-AF in sample 3854 make partitioning of the dataset more complex. This means that it is necessary to make further comparison(s) using other major and/or trace element data. Moreover, this type of comparison is somewhat subjective, because it is based on visual evaluation of chemical data on a 


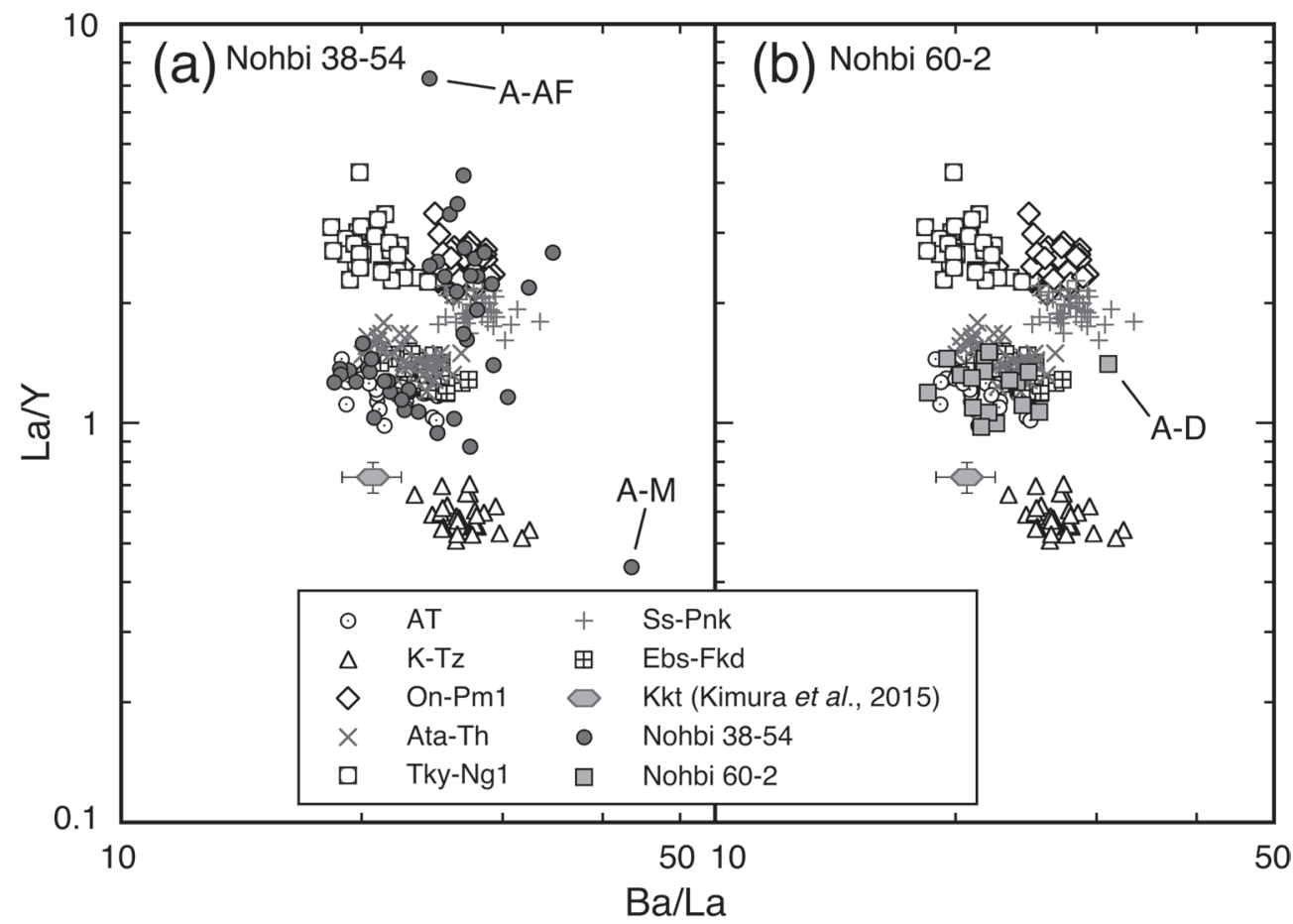

Fig. 4 Plots of $\mathrm{La} / \mathrm{Y}$ vs Ba/La $(\mu \mathrm{g} / \mathrm{g})$ for volcanic glass shards in the Nohbi samples

The AT data obtained by NWR-fsLA are plotted on this figure. "A-M" and "A-AF" in (a) indicate analysis spots M and AF on mount A of the Nohbi 38-54 sample. “A-D” in (b) indicates analysis spot D on mount A of the Nohbi 60-2 sample. The ratios for Kkt was calculated from the data determined by Kimura et al. (2015).

bivariate plot, although some mathematical techniques such as linear discriminant analysis are sometimes used for such evaluations (e.g., Nogami et al., 2018).

The concentrations and/or ratios of some relatively abundant trace elements are useful for the grouping and identification of tephras (Fig. 4). However, using this method, it is difficult to evaluate and quantify in detail the relationships amongst the individual spot/shard analyses. Therefore, hierarchical cluster analysis was used in this study to distinguish glass chemistry populations with less subjectivity.

\section{Cluster analysis}

Firstly, potential differences due to the three different LA instruments used in this study were evaluated. In addition, the ranges of the branches (Euclidean distances) of each pure tephra sample were estimated to partition the volcanic glass shards of the Nohbi Formation samples into individual tephra components. The analytical data belonging to the same branch with a maximum height equivalent to that of the pure tephra can be used to identify the specific tephra.

Figure 5 compares the dendrograms of the pure AT tephra sample obtained by NWR-fsLA on six AT glass shards, NWR-exLA on five AT glass shards, and CL-fsLA on one AT glass shard. The maximum heights (distances) of the NWR-fsLA, NWR-exLA, and CL-fsLA data are 281.6, 239.2, and 256.7, respectively (Fig. 5). There is no significant difference between the fsLA and exLA data (Fig. 5-a and b). Moreover, the maximum height obtained from 20 analyses of the single AT glass shard is intermediate between those of the NWR-fsLA and NWR-exLA data on numerous AT glass shards (Fig. 5-a and b). These results suggest that the cluster analysis is not affected by the different instruments and LA conditions. Figure 6 shows the dendrograms obtained from the Ebs-Fkd, On- 
(a)

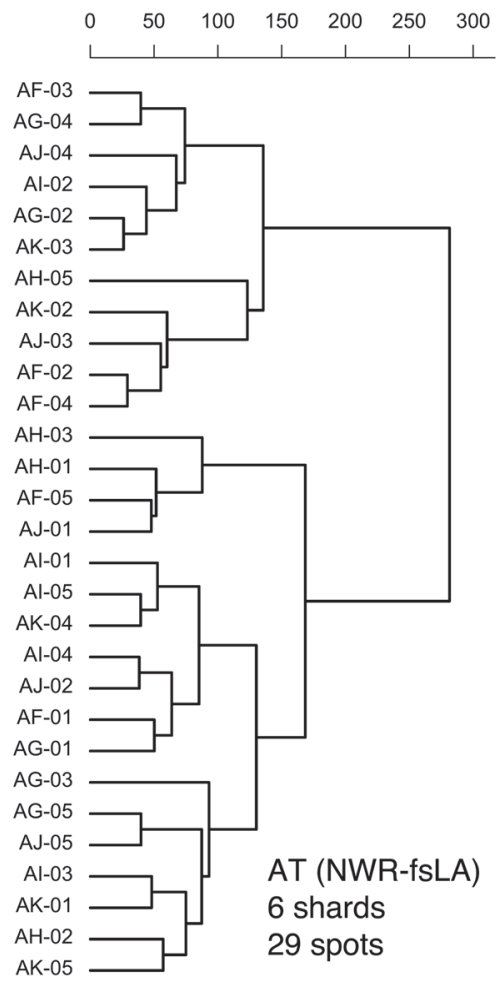

(b)

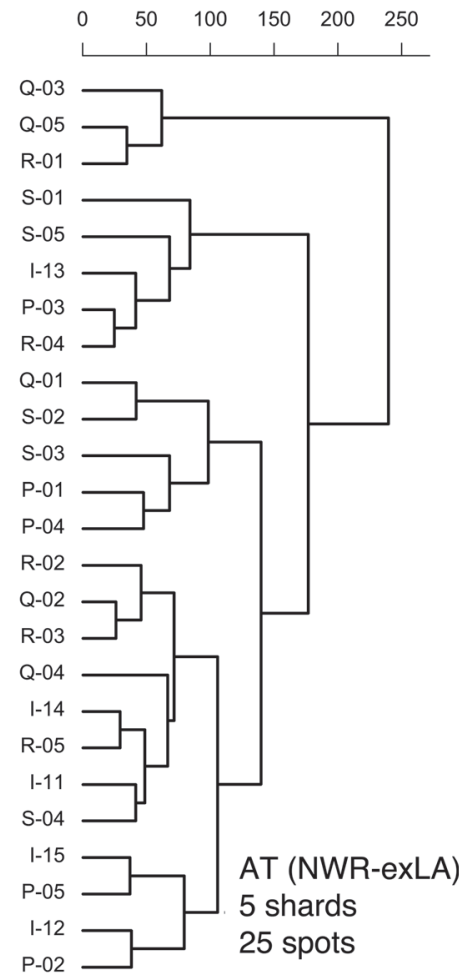

(c)

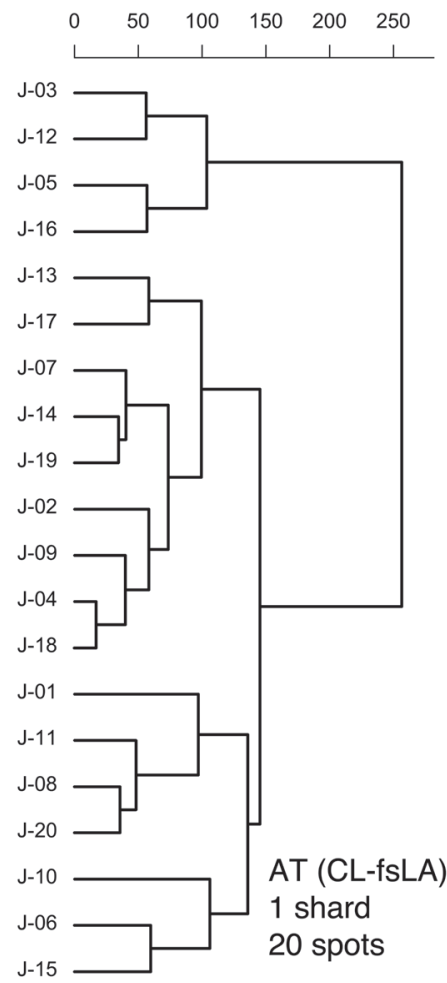

Fig. 5 Dendrograms for AT volcanic glass shards analyzed by (a) NWR-fsLA, (b) NWR-exLA, and (c) CL-fsLA The total numbers of analyzed shards and spots for each LA analysis are shown at lower left in each dendrogram. The lettering and numbering of each analysis represent the glass shard name and analysis number of the glass shard, respectively. For example, "AF-03" in (a) represents the third analysis of the AF glass shard.

Pml, and Tky-Ng1 tephra data. The maximum heights of the branches of Ebs-Fkd, On-Pm1, and Tky-Ng1 are 286.3, 333.5, and 261.0, respectively. These values are generally equivalent to those obtained from the AT data (Fig. 5). The maximum height of the branches obtained from the cluster analysis of pure tephra samples was 240-340.

Figure 7 shows the dendrograms obtained from the Nohbi Formation sample data. Figures 8 and 9 show the elemental patterns of each separated tephra relative to crustal abundances (Taylor and McLennan, 1985 ; Rudnick and Fountain, 1995 ; McLennan and Taylor, 1996 ; McLennan, 2001) based on the results of the cluster analysis shown in Fig. 7. The data for sample 38-54 are divided into Groups A (A-AP$\mathrm{A}-\mathrm{AQ})$ and $\mathrm{B}(\mathrm{A}-\mathrm{B}-\mathrm{A}-\mathrm{AK})$ in the first branching
(Fig. 7-a). The elemental pattern obtained from Group A is similar to that of the AT tephra (Fig. 8-a), and can be classified as AT glass shards. Group B is subdivided into Groups C (A-B-A-AN) and D (A-AW-A-AK) (Fig. 7-a). The elemental patterns of Groups $\mathrm{C}$ and D are generally similar to those of the Ebs-Fkd and On-Pm1 tephras, respectively (Fig. 8-b). In particular, the pattern of Group D exhibits an obvious Y-depletion, which is a characteristic of the On-Pm1 tephra. The patterns of Groups C and D are distinguishable from those of the Ata-Th and Ss-Pnk tephras (Fig. 8-b). The analyses of shards A-M and A-AF, which deviate from the other data in Fig. 4-a, are identified as the AT (Group A) and OnPml (Group D) tephras, respectively. The maximum heights of the branches of Groups A (217.1), C (269.6), and D (340.3) are slightly below or 
(a)

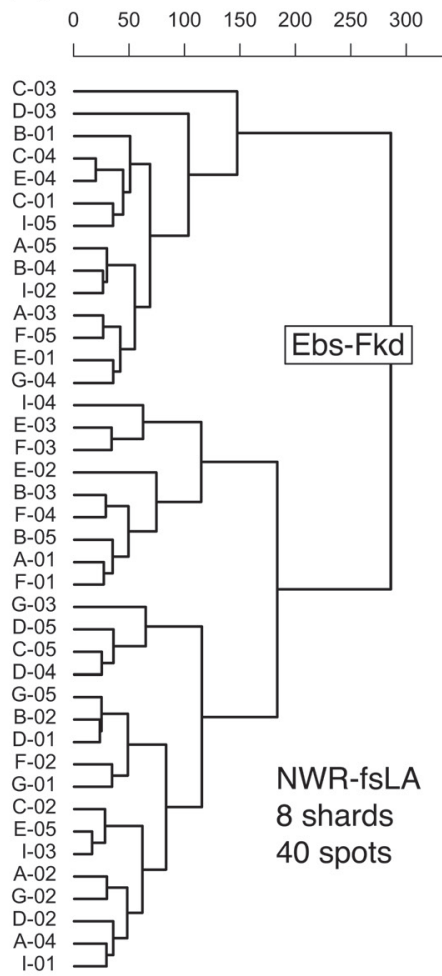

(b)
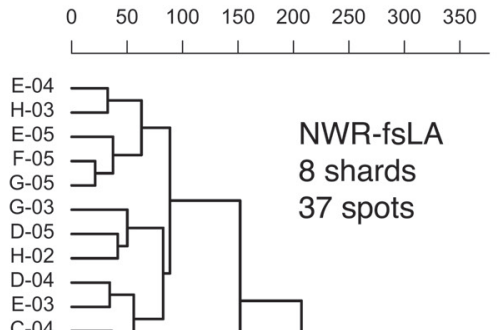

(c)
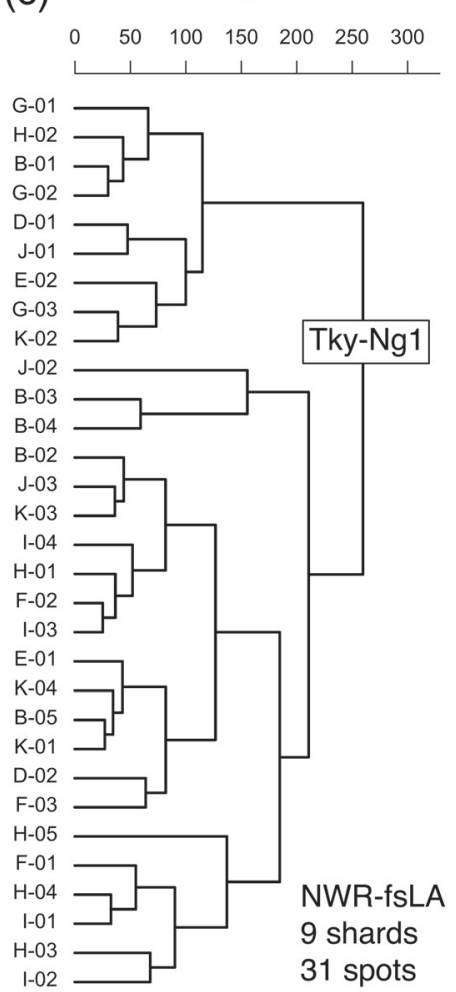
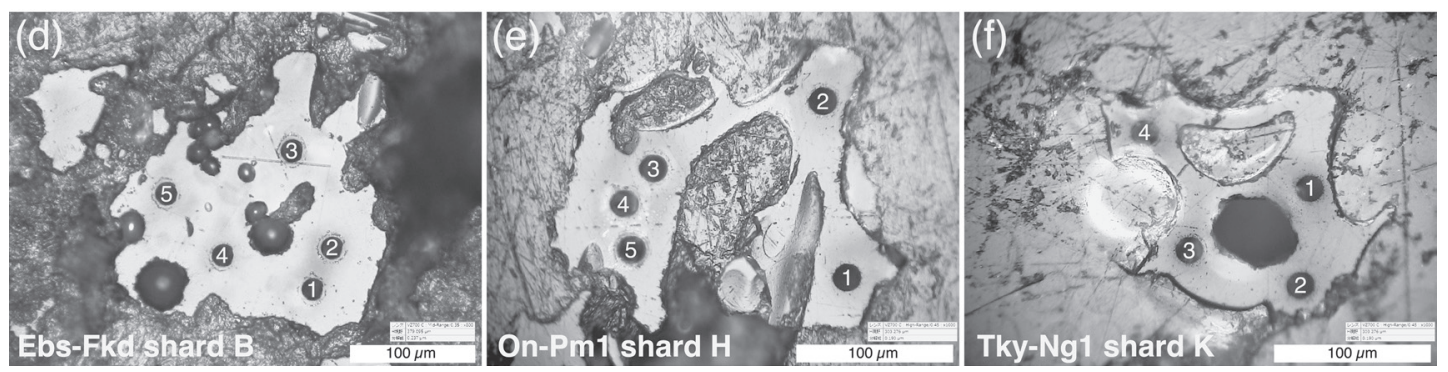

Fig. 6 Dendrograms for volcanic glass shards in the (a) Ebs-Fkd, (b) On-Pm1, and (c) Tky-Ng1 tephras, and optical images of volcanic glass shards of (d) Ebs-Fkd, (e) On-Pml, and (f) Tky-Ngl tephras after laser ablation

The notation for the analysis spots is the same as for Fig. 5. In (d), (e), and (f), the analysis numbers are shown on the LA pits on the volcanic glass shards. The shapes of the volcanic glass shards shown in (d), (e), and (f) can be classified into a pumiceous type.

almost identical to those of the pure tephra samples. Therefore, sample $38-54$ can be shown by cluster analysis to contain three tephras, in the following proportions : AT $=44 \%$, Ebs-Fkd $=$ $23 \%$, and $\mathrm{On}-\mathrm{Pm} 1=33 \%$. There are some slight deviations in elements such as $\mathrm{Li}, \mathrm{Er}, \mathrm{Tm}$, and $\mathrm{W}$ in the mean values for Groups $\mathrm{C}$ and $\mathrm{D}$ (Fig. 8-b). These deviations appear to be due to the smaller number of analyses used for calculation of the mean values, rather than the effect of secondary alteration or the incorporation of other unknown tephra(s).

Sample 60-2 can be divided into two groups (Fig. 7-b). Group A (B-K-A-I) corresponds to the AT tephra and Group B (A-L-B-F) corresponds to the Ebs-Fkd tephra. The maximum heights of the branches of Groups A (213.3) and B (269.0) are slightly lower than those of the pure tephra 
(a)
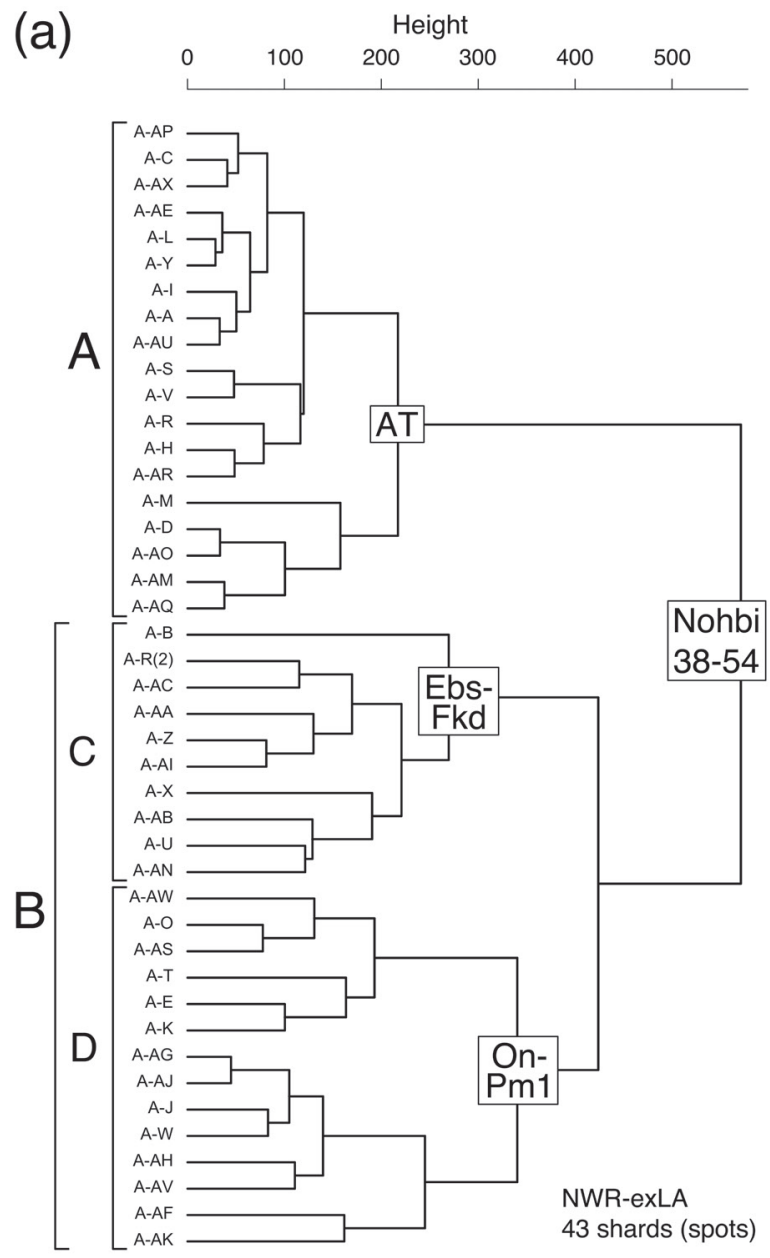

(b)
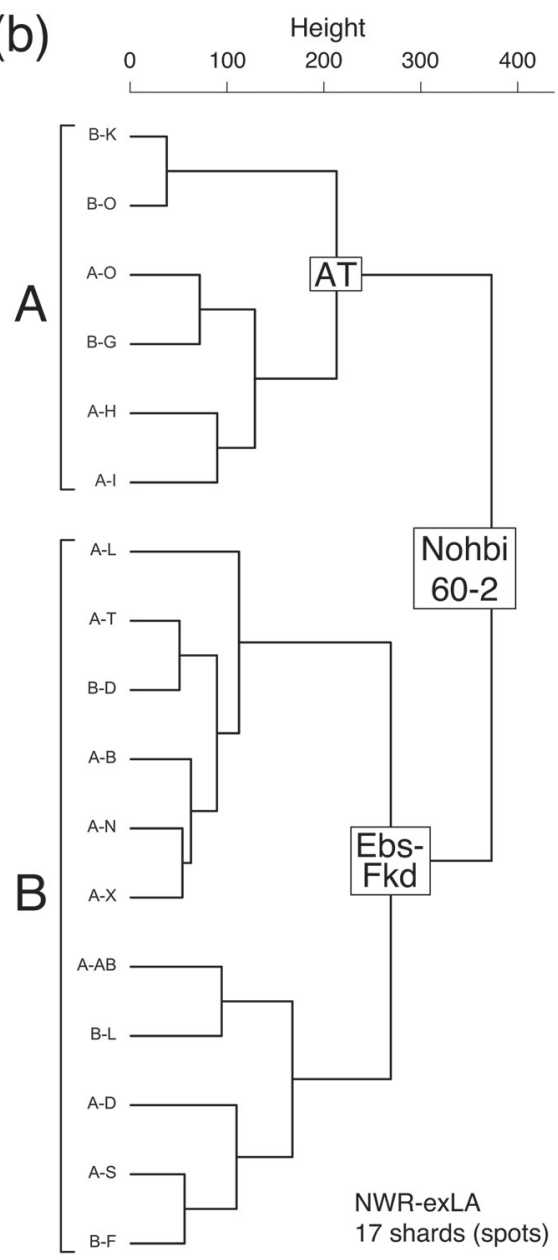
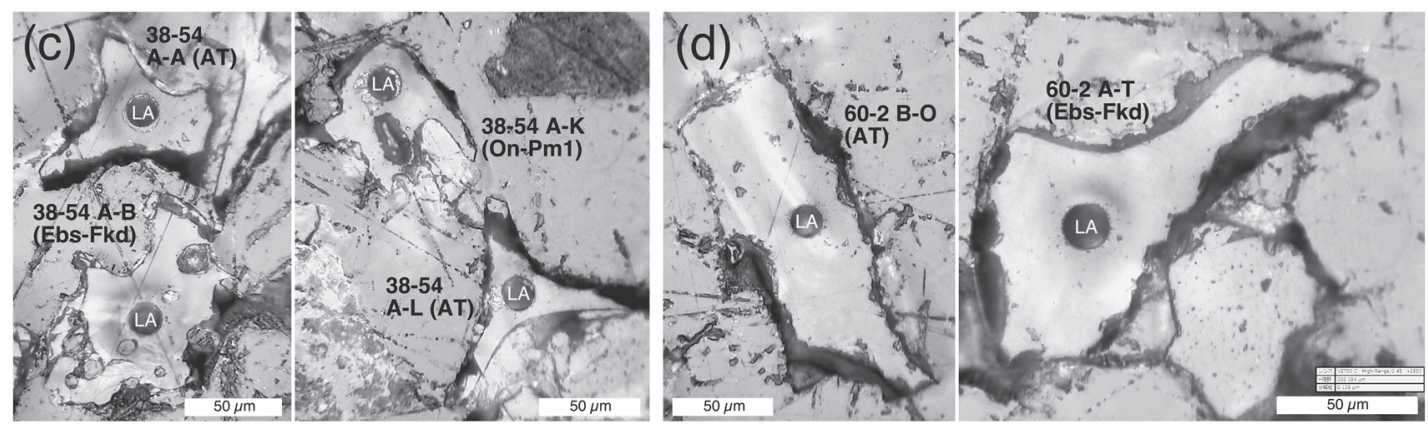

Fig. 7 Dendrograms for volcanic glass shards in the Nohbi (a) 38-54 and (b) 60-2 samples, and optical images of volcanic glass shards in the Nohbi (c) 38-54 and (d) 60-2 samples after laser ablation

The volcanic glass shards in sample Nohbi 38-54 can be divided into the AT, Ebs-Fkd, and On-Pm1 tephras. Those in sample Nohbi 60-2 can be divided into the AT and Ebs-Fkd tephras. The letter labeling of each analysis spot refers to the resin mount and glass shard. For example, "A-AP" in (a) represents the glass shard AP in mount A. "LA" on the optical images (c) and (d) represent the LA pits. The glass shards classified as AT have an appearance of the bubble wall type. The shapes of those classified as Ebs-Fkd and On-Pml are pumiceous/intermediate types. 


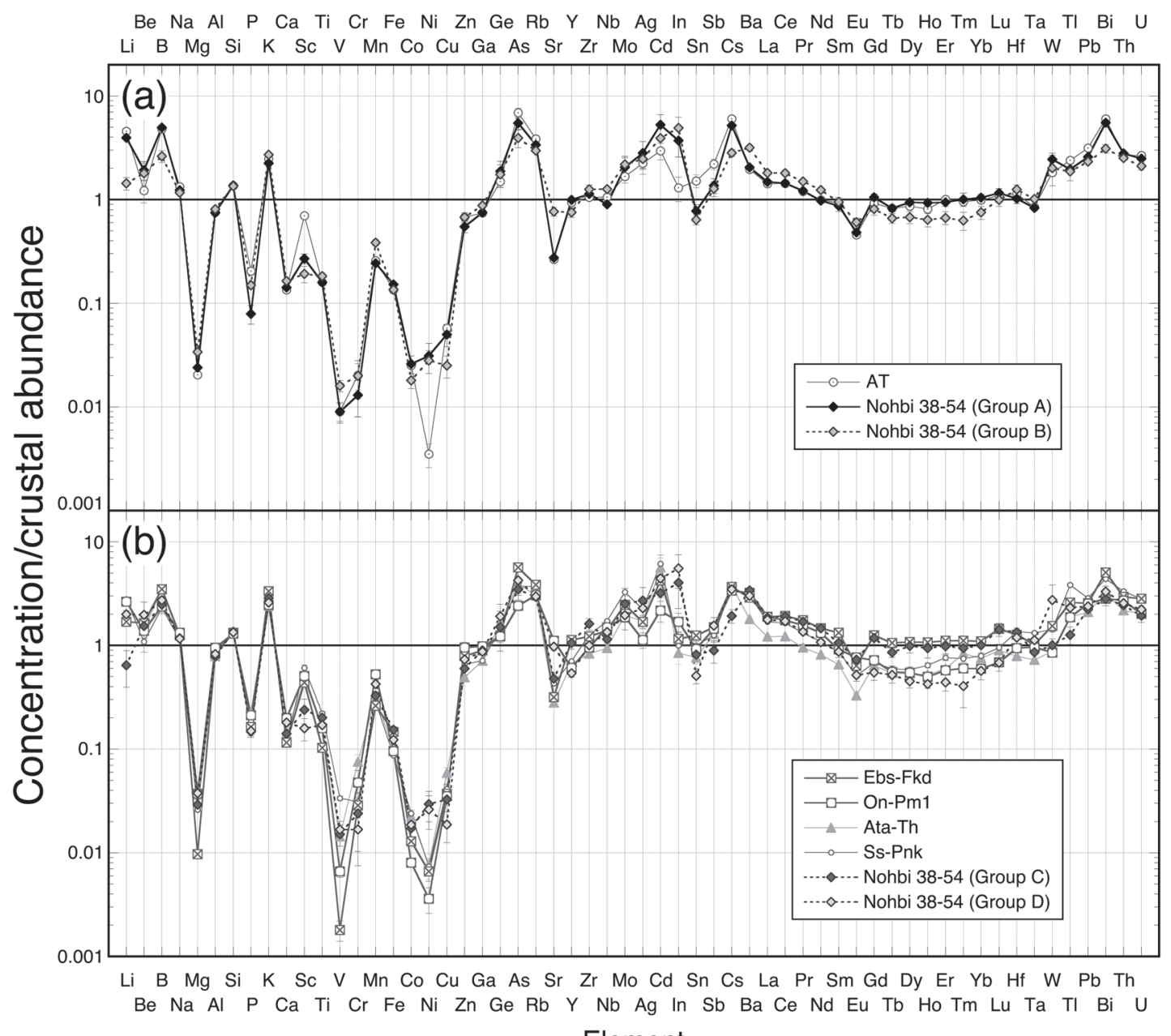

Element

Fig. 8 Mean elemental patterns for the glass shards in (a) Groups A and B, and (b) Groups C and D from the Nohbi 38-54 sample (Fig. 7)

All errors are $1 \sigma_{\text {mean }}$.

samples. The shard analysis A-D that deviates from the distribution of the AT, Ebs-Fkd, and Ss-Pnk tephras in Fig. 4-b is identified as the Ebs-Fkd tephra (Group B). As for sample 38-54, the mean data values for each group show slight deviations (e.g., heavy rare earth elements and Hf for Group A ; Fig. 9). Nevertheless, the major elements (e.g., $\mathrm{Mg}$ ), $\mathrm{Y}-\mathrm{Nb}$, and light rare earth elements successfully identify the AT and EbsFkd tephras in sample 60-2. The analysis data for some shards overlap with the distribution of Ata-Th in Fig. 4-b. However, the patterns of Groups A and B are obviously different from that of the Ata-Th tephra (Fig. 9). The cluster analysis indicates that the proportions of the AT and Ebs-Fkd tephras in sample 60-2 are 35\% and $65 \%$, respectively.

The shapes of the volcanic glass shards in the Nohbi Formation samples can be classified into bubble wall type, or an intermediate type between bubble wall and pumiceous (Takoushitsu of Yoshikawa, 1976) types (Makinouchi et al., 2001) (Fig. 7-c and d). As with the volcanic glass shards of Ebs-Fkd (Fig. 6-d) and Tky-Ng1 (Fig. 6-f), those of On-Pm1 are typically pumiceous (Kobayashi et al., 1967 ; Takemoto et al., 1987) 


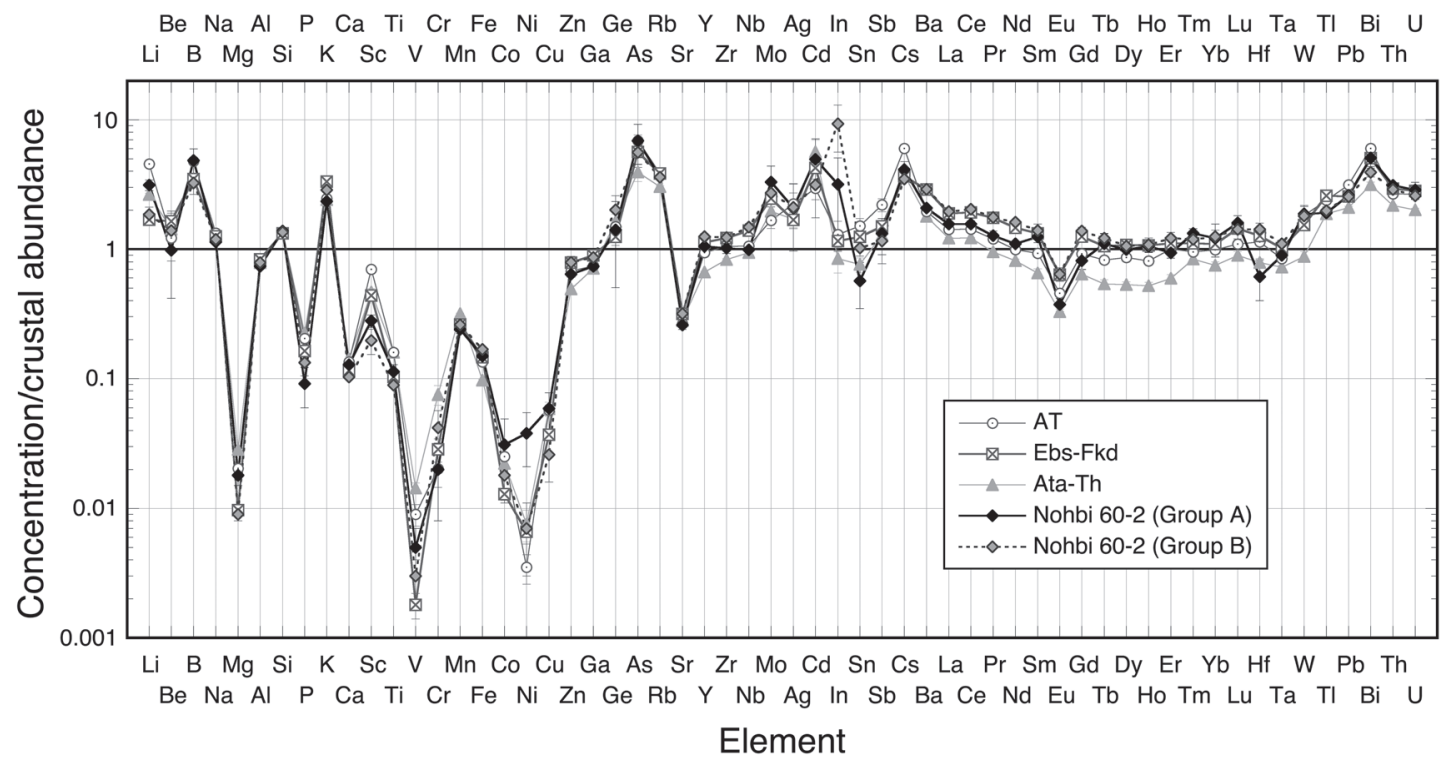

Fig. 9 Mean elemental patterns for the glass shards in Groups A and B from the Nohbi 60-2 sample (Fig. 7) All errors are $1 \sigma_{\text {mean }}$.

(Fig. 6-e). However, some crushed pumice can produce shards with an appearance similar to the bubble wall type. The glass shards of OnPm1 with bubble wall or intermediate type shapes (i.e., lower porosity types; Fig. 7-c) may have been deposited on the Nohbi Plain with little water transport. The catchment area of the Kiso River includes Ontake volcano, and the upper reaches of the Kiso River run through eastern Ontake volcano (e.g., Ministry of Land, Infrastructure and Transport, 2008). Therefore, the Kiso River may have transported the OnPml pumice grains to the Nohbi Plain from the area where the On-Pm1 tephra fallout occurred (Kobayashi et al., 1967).

The AT tephra (30 ka ; Albert et al., 2018) and the tephras which are older than AT were detected from the Nohbi muddy sediments by the cluster analysis. Therefore, the depositional age of the Nohbi Formation cannot be backdated before the AT eruption age. However, it is difficult to identify the AT ash fall horizon in the Nohbi Formation, because samples 38-54 and 60-2 contain the AT volcanic glass shards. The presence of the AT volcanic glass shards implies that the Nohbi Formation was deposited during and/or after the AT ash fall. The more precise dating of the deposition of the Nohbi Formation is further problem.

Combined cluster analysis of major and various trace elements may be advantageous, in terms of the number of "decision factors" available for statistical analysis. However, considering the preliminary tests conducted in this study, there are still some subjective decisions that can control the results of cluster analysis. For example, some low-concentration elements have little effect on the results of cluster analysis. In contrast, relatively abundant trace elements are essential for the statistical analysis. Nogami et al. (2018) suggested that the trace elements Rb, $\mathrm{Sr}, \mathrm{Y}, \mathrm{Zr}, \mathrm{La}$, and Ce are suitable for tephra identification. In addition to these elements, $\mathrm{Ba}$ (e.g., Tamura et al., 2005, 2008) should also be included in the statistical analysis, given the high abundance of $\mathrm{Ba}$ in rhyolitic glass shards and the comparison shown in Fig. 4. However, it may be unnecessary to select specific elements for statistical analysis, given the fact that principal component analysis can rapidly identify components in datasets. As such, it may better to undertake the statistical analysis on the full suite of analyzed elements. 


\section{Conclusions}

To identify the presence of the AT tephra in the Nohbi Formation, the concentrations of 58 major and trace elements in volcanic glass shards were determined by LA-ICP-MS. The relationship between the $\mathrm{Ba} / \mathrm{La}$ and $\mathrm{La} / \mathrm{Y}$ ratios of the volcanic glass shards from sample 38-54 suggested that it contains the AT and On-Pm1 tephras, although the presence of Ebs-Fkd is equivocal. On the other hands, that of the volcanic glass shards from sample 60-2 suggested that it contains the AT and Ebs-Fkd tephras.

Hierarchical cluster analysis was applied to the elemental concentration data for the Nohbi Formation samples. From the cluster analysis results, the volcanic glass shards in sample 3854 were identified as being the AT (44\%), EbsFkd (23\%), and On-Pm1 (33\%) tephras, and those in sample 60-2 were identified as the AT (35\%) and Ebs-Fkd (65\%) tephras. Our results confirm those of Makinouchi et al. (2001), in that the Nohbi Formation contains AT volcanic glass shards. This result indicates that the Nohbi Formation was deposited during and/or after the AT ash fall stage.

The results of this study demonstrate that a combination of LA-ICP-MS multi-element data and cluster analysis can rapidly and objectively identify different glass populations in sediments.

\section{Acknowledgements}

Comments by two anonymous reviewers improved the quality of this paper. We thank Y. Satoguchi for the editorial handling and review. This study was partly supported by Grants-inAid for Scientific Research (A26247094 to T. Hirata ; 17K05720 to S. Maruyama) from the Ministry of Education, Culture, Sports, Science, and Technology (MEXT), Japan. Without kind advice given by persons mentioned above, we could not complete this manuscript.

\section{References}

Albert, P.G., Smith, V.C., Suzuki, T., Tomlinson, E.L., Nakagawa, T., McLean, D., Yamada, M., Staff, R.A., Schlolaut, G., Takemura, K., Nagahashi, Y., Kimura, J. and Suigetsu 2006 Project Members (2018) Constraints on the frequency and dispersal of explosive eruptions at Sambe and Daisen volcanoes (SouthWest Japan Arc) from the distal Lake Suigetsu record (SG06 core). Earth-Science Reviews, 185, 1004-1028.

Aramaki, S. and Ui, T. (1976) Pyroclastic deposits in southern Kyushu-A correlation by the Ca-Mg-Fe ratios of the phenocrystic minerals. Bulletin of the Earthquake Research Institute, 51, 151-182. (J+E)

Baron, D., Negrini, R.M., Golob, E.M., Miller, D., SarnaWojcicki, A., Fleck, R.J., Hacker, B. and Erendi, A. (2008) Geochemical correlation and ${ }^{40} \mathrm{Ar} /{ }^{39} \mathrm{Ar}$ dating of the Kern River ash bed and related tephra layers : Implications for the stratigraphy of petroleumbearing formations in the San Joaquin Valley, California. Quaternary International, 178, 246-260.

Danhara, T., Yamashita, T., Iwano, H. and Kasuya, M. (1992) An improved system for measuring refractive index using the thermal immersion method. Quaternary International, 13/14, 89-91.

Furukawa, H. (1972) Alluvial deposits of the Nohbi Plain, central Japan. The memoirs of the Geological Society of Japan (Chishitsugaku-ronshu), 7, 39-59. $(\mathrm{J}+\mathrm{E})$

Hori, K., Hasada, K., Ishii, Y. and Takahashi, E. (2019) Late Pleistocene to Holocene sedimentary sequence and landform of the Nobi Plain, central Japan. The Journal of the Geological Society of Japan (Chishitsugakuzasshi), 125, 73-85. (J+E)

Iseki, H. (1962) Fundamental problems on the alluvial plain. The Journal of the Faculty of Letters, Nagoya University (Nagoya Daigaku Kenkyu-ronshu), 26, 51-74. $(\mathrm{J})^{*}$

Jochum, K.P., Weis, U., Stoll, B, Kuzmin, D., Yang, Q., Raczek, I., Jacob, D.E., Stracke, A., Birbaum, K., Frick, D.A., Günther, D. and Enzweiler, J. (2011) Determination of reference values for NIST SRM 610-617 glasses following ISO guidelines. Geostandards and Geoanalytical Research, 35, 397-429.

Kajita, S. and Ishihara, T. (1977) The Quaternary deposits of Takayama district in the Hida high land. The memoirs of the Geological Society of Japan (Chishitsugakuronshu), 14, 151-159. (J+E)

Kamata, H. (1989) Shishimuta caldera, the buried source of the Yabakei pyroclastic flow in the Hohi volcanic zone. Bulletin of Volcanology, 51, 41-50.

Kikkawa, K. (1990) Identification of tephra layers by inductively coupled plasma (ICP) emission spectrometry, and their applications. Journal of Geography (Chigaku-zasshi), 99 (7), 11-26. (J+E)

Kikkawa, K., Imai, N., Okumura, K. and Mizuno, K. (1989) Identification of tephra layers by chemical analyses of volcanic glass using inductively coupled plasma emission spectrometry (ICP). Bulletin of the Geological Survey of Japan, 40, 1-18. (J+E)

Kimura, J., Nagahashi, Y., Satoguchi, Y. and Chang, Q. (2015) Origins of felsic magmas in Japanese subduction zone : geochemical characterizations of tephra from caldera-forming eruptions $<5 \mathrm{Ma}$. Geochemistry, Geophysics, Geosystems, 16, 2147-2174.

Kobayashi, K., Shimizu, H., Kitazawa, K. and Kobayashi, 
T. (1967) The pumice-fall deposit "Pm-I" supplied from Ontake volcano : Study of the pumice-fall deposit "PmI” supplied from Ontake volcano No. 1. The Journal of the Geological Society of Japan (Chishitsugakuzasshi), 73, 291-308. (J+E)

Kondo, Y. (1985) Stratigraphy of the upper Pleistocene in the Udo Hills, Shizuoka prefecture, Japan. The Journal of the Geological Society of Japan (Chishitsugakuzasshi), 91, 121-140. (J+E)

Kuwahara, T. (1968) The Noobi basin and its fault block movements. The Quaternary Research (Daiyonkikenkyu), 7, 235-247. (J+E)

Kuwahara, T. (1985) Chapter 3 : Groundwater basin in the Nohbi Plain. The Tokai Ground Subsidence Exmination Committee (ed.) Ground subsidence and groundwater in the Nohbi Plain : 35-76, The University of Nagoya Press. $(\mathrm{J})^{*}$

Kuwahara, T. and Makinouchi, T. (1988) Chapter 2 : Subsurface geology in the subsoils in Nagoya. in Geotechnical Data of Subsoils in Nagoya (New edition). Publication Committee of Subsoils in Nagoya. 15-36. $(\mathrm{J})^{*}$

Lowe, D.J., Pearce, N.J.G., Jorgensen, M.A., Kuehn, S.C., Tryon, C.A. and Hayward, C.L. (2017) Correlating tephras and cryptotephras using glass compositional analyses and numerical and statistical methods : Review and evaluation. Quaternary Science Reviews, $175,1-44$

Machida, H. and Arai, F. (2011) Atlas of Tephra in and around Japan (second impression of the revised edition). 336 p. University of Tokyo Press. (J)

Makinouchi, T., Mori, S., Danhara, T., Takemura, K. and Geologic profile WG of Research Committee for the Ground of Nohbi Plain (2001) Ages of the basal gravel of Alluvium (BG) and the lower marine clay member of late Pleistocene Atsuta Formation under the Nohbi Plain, central Japan-Fruitful results based on tephra analyses of core samples recovered from the coastal area. The Journal of the Geological Society of Japan (Chishitsugaku-zasshi), 107, 283-295. $(\mathrm{J}+\mathrm{E})$

Makinouchi, T., Mori, S., Danhara, T. and Takemura, K. (2006) Stratigraphic horizon and formational process of the First Gravel Formation (BG) in the Nohbi Plain. The memoirs of the Geological Society of Japan (Chishitsugaku-ronshu), 59, 129-140. (J+E)

Makinouchi, T., Tsukamoto, M., Danhara, T., Yamashita, T., Uchizono, T. and Geologic Profile WG of Research Committee for the Ground of Nohbi Plain (2013) Subsurface geology in the eastern part of the Nohbi Plain, Aichi Prefecture, central Japan. The Journal of the Geological Society of Japan (Chishitsugakuzasshi), 119, 335-349. (J+E)

Maruyama, S., Hattori, K., Hirata, T. and Danhara, T. (2016a) A proposed methodology for analyses of wide-ranged elements in volcanic glass shards in widespread Quaternary tephras. Quaternary International, 397, 267-280.
Maruyama, S., Hattori, K., Hirata, T., Suzuki, T. and Danhara, T. (2016b) Simultaneous determination of 58 major and trace elements in volcanic glass shards from the INTAV sample mount using femtosecond laser ablation-inductively coupled plasma-mass spectrometry. Geochemical Journal, 50, 403-422.

Maruyama, S., Danhara, T. and Hirata, T. (2017) Reidentification of Shishimuta-Pink tephra samples from the Japanese Islands based on simultaneous major- and trace-element analyses of volcanic glasses. Quaternary International, 456, 180-194.

Maruyama, S., Takemura, K., Hirata, T., Iwano, H., Yamashita, T. and Danhara, T. (2018) Identification and correlation of tephras from the Plio-Pleistocene Shobudani Group, Kinokawa River, southwest Japan. The Quaternary Research (Daiyonki-kenkyu), 57, 211-227.

Matsuzawa, I. and Kato, Y. (1954) Geological map of Nagoya, 1 : 25,000. Aichi Prefecture. $(\mathrm{J})^{*}$

Matumoto, T. (1943) The four gigantic caldera volcanoes of Kyushu. Japanese Journal of Geology and Geography, 19, 1-57.

McLennan, S.M. (2001) Relationships between the trace element composition of sedimentary rocks and upper continental crust. Geochemistry, Geophysics, Geosystems, 2, Paper number 2000GC000109.

McLennan, S.M. and Taylor, S.R. (1996) Heat flow and the chemical composition of continental crust. The Journal of Geology, 104, 369-377.

Ministry of Land, Infrastructure and Transport (2008) The Kiso, Nagara, and Ibi Rivers. http://www.mlit. go.jp/river/toukei_chousa/kasen/jiten/nihon_kawa/ 0509_kiso/0509_kiso_00.html, Retrieved May 30, 2019. (J)

Mizuno, K. and Kikkawa, K. (1991) Consideration on the extent of a middle Pleistocene tephra, the Ng-1 ash in central Japan. The Quaternary Research (Daiyonkikenkyu), 30, 435-438. (J+E)

Nagahashi, Y., Satoguchi, Y. and Yoshikawa, S. (2000) Correlation and stratigraphic eruption age of the pyroclastic flow deposits and wide spread volcanic ashes intercalated in the Pliocene-Pleistocene strata, central Japan. The Journal of the Geological Society of Japan (Chishitsugaku-zasshi), 106, 51-69. (J+E)

Nagahashi, Y., Yoshikawa, S., Miyakawa, C., Uchiyama, T. and Satoguchi, Y. (2004) Relationship between major element composition and refractive index of volcanic glass. The Quaternary Research (Daiyonkikenkyu), 43, 345-352. (J+E)

Nobi Plain Quaternary Research Group (1977) Stratigraphy and microfossil analysis of Quaternary sediments in the Nobi plain. The memoirs of the Geological Society of Japan (Chishitsugaku-ronshu), 14, 161-183. $(\mathrm{J}+\mathrm{E})$

Nogami, T., Abe, Y. and Nakai, I. (2018) Trace-element analysis of volcanic glass shards by laser ablation ICP-MS for forensic soil analysis. Bunseki Kagaku, 67, 485-491. (J+E) 
Parks, J.M. (1966) Cluster analysis applied to multivariate geologic problems. The Journal of Geology, 74, 703715.

Pisias, N.G., Murray, R.W. and Scudder, R.P. (2013) Multivariate statistical analysis and partitioning of sedimentary geochemical data sets : General principles and specific MATLAB scripts. Geochemistry, Geophysics, Geosystems, 14, 4015-4020.

R Core Team (2019) R : A language and environment for statistical computing. R Foundation for Statistical Computing, Vienna, Austria. https://www.R-project. org/, Retrieved May 30, 2019.

Rhodes, J.M. (1969) The application of cluster and discriminatory analysis in mapping granite intrusions. Lithos, 2, 223-237.

Rudnick, R.L. and Fountain, D.M. (1995) Nature and composition of the continental crust : A lower crustal perspective. Reviews of Geophysics, 33, 267-309.

Scudder, R.P., Murray, R.W., Kutterolf, S., Schindlbeck, J.C., Underwood, M.B. and Wang, K-L. (2018) Sedimentary inputs to the Nankai subduction zone: The importance of dispersed ash. Geosphere, 14 (4), 1-17.

Shimada, S. (2000) Eruption of the Amagi-Kawagodaira Volcano and paleo-environments in the late and latest Jomon periods around the Izu Peninsula. The Quaternary Research (Daiyonki-kenkyu), 39, 151164. $(\mathrm{J}+\mathrm{E})$

Sugai, T., Sato, T., Mizuno, K. and Sugiyama, Y. (2016) Magnitudes of sea-level falls at lowstands of the past 900,000 years inferred from gravels underlying Nobi Plain, central Japan. Quaternary International, 397, 422-435.

Takemoto, H., Momose, M., Hirabayashi, K. and Kobayashi, T. (1987) Stratigraphy and correlation of the younger Ontake tephra group-An implication to the late Pleistocene chronology in central Japan. The Qua- ternary Research (Daiyonki-kenkyu), 25, 337-352. $(\mathrm{J}+\mathrm{E})$

Tamura, I., Yamazaki, H. and Mizuno, K. (2005) The Sakai volcanic ash and its correlatives : a 4.1-Ma (Early Pliocene) widespread tephra in Japan. The Journal of the Geological Society of Japan (Chishitsugakuzasshi), 111, 727-736. (J+E)

Tamura, I., Yamazaki, H. and Mizuno, K. (2008) Characteristics for the recognition of Pliocene and early Pleistocene marker tephras in central Japan. Quaternary International, 178, 85-99.

Taylor, S.R. and McLennan, S.M. (1985) The continental crust : its composition and evolution. 312 p, Blackwell Scientific Publications, Cambridge, Massachusetts.

Till, R. (1974) Statistical methods for the earth scientist : an introduction. $154 \mathrm{p}$, Macmillan.

Tryon, C.A., Roach, N.T. and Logan, M.A.V. (2008) The Middle Stone Age of the northern Kenyan Rift : age and context of new archaeological sites from the Kapedo Tuffs. Journal of Human Evolution, 55, 652664.

Yoshikawa, S. (1976) The volcanic ash layers of the Osaka Group. The Journal of the Geological Society of Japan (Chishitsugaku-zasshi), 82, 497-515. (J+E)

(J) in Japanese, $(\mathrm{J}+\mathrm{E})$ in Japanese with English abstract. * Title etc. translated by T.M.

The following appendixes are published as electronic appendixes on the website of The Quaternary Research (Daiyonki-kenkyu).

〈http://quaternary.jp/journals/data.html〉

Appendix S1 Analytical results of volcanic glass shards

Appendix S2 Euclidean distances among analysis data for the individual tephra samples 


\title{
火山ガラスの化学組成に基づく濃尾層泥質堆積物中の 広域テフラの識別
}

\author{
丸山誠史 ${ }^{* 1,2, a}$ - 牧野内 猛*3 . 平田岳史 ${ }^{* 4}$ - 檀原 徹*1
}

\begin{abstract}
[要旨 $]$
後期更新世の濃尾層に含まれる泥質堆積物中の火山ガ ラスは，複数のテフラに由来するものと考えられる，濃 尾層泥質堆積物の火山ガラスをグループ分けするため に，LA-ICP-MS を用いて測定された，火山ガラスの 58 種の元素濃度データの階層的クラスター分析を適用した。 クラスター分析の結果から, 濃尾層基底の試料 (Nohbi 38-54）に含まれる火山ガラスは，姶良 $\mathrm{Tn}(44 \%)$ ，御岳 第 1 (33\%), 恵比寿峠福田 (23\%)に分けられた。また, 濃尾層中部の試料 (Nohbi 60-2) に含まれる火山ガラス

た. LA-ICP-MS を用いて測定された多元素同時分析と 測定データのクラスター分析によって, 先行研究で示唆 された通り，濃尾層の泥質堆積物中に数十\%の姶良 $\mathrm{Tn}$ の火山ガラスが存在している証拠が得られた，濃尾層に 多量の姶良 Tn テフラ成分が存在し，姶良 Tn テフラが 最も新しいテフラ成分であることは, 濃尾層の堆積年代 に制約を与えるものである。この結果に基づけば，濃尾 層は姶良 Tn テフラの降灰期間中，あるいは降灰後に堆 積したと考えられる.
\end{abstract} は，姶良 Tn $(35 \%)$ と恵比寿峠福田 $(65 \%)$ に分けられ

キーワード : テフラ, 火山ガラス, 泥質堆積物, 濃尾層, クラスター分析, LA-ICP-MS

*1 株式会社京都フィッション・トラック † 603-8832 京都市北区大宮南田尻町 44-4.

*2 同志社大学文化遺産情報科学調查研究センター $=$ \% 610-0394 京都府京田辺市多々羅都谷 1-3.

*3 (元) 名城大学理工学部環境創造学科 T468-8502 名古屋市天白区塩釜口 1-501.

*4 京都大学大学院理学研究科地球惑星科学専攻 ₹606-8502 京都市左京区北白川追分町. (現所属 : 東京大学大学院理学 系研究科地殼化学実験施設 $=113-0033$ 東京都文京区本郷 7-3-1.)

*a Corresponding author : ojigibito@icloud.com 